QQ

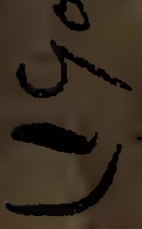

$A-0[$ sgood]

D. Alaska
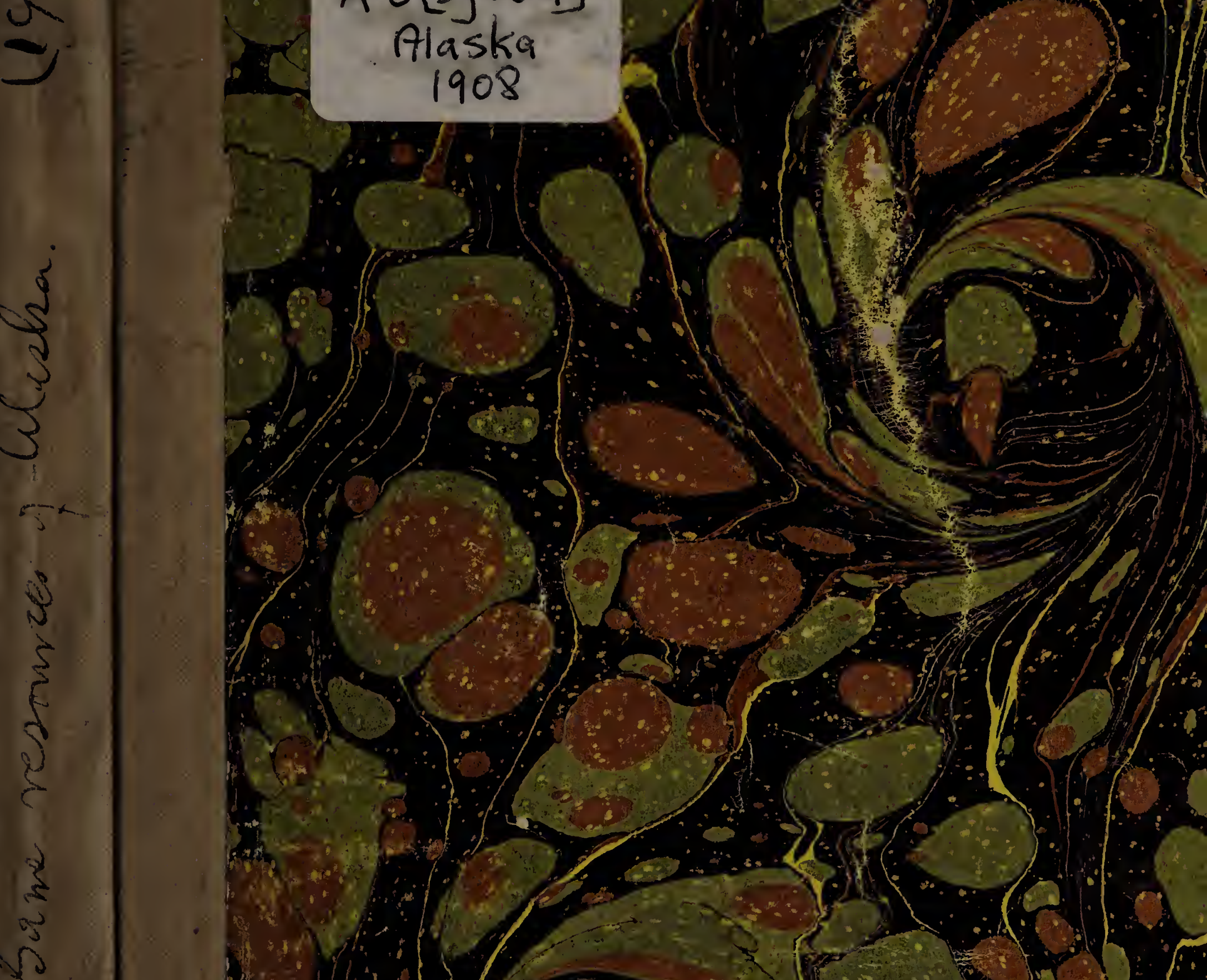

$10+\frac{1}{0}$
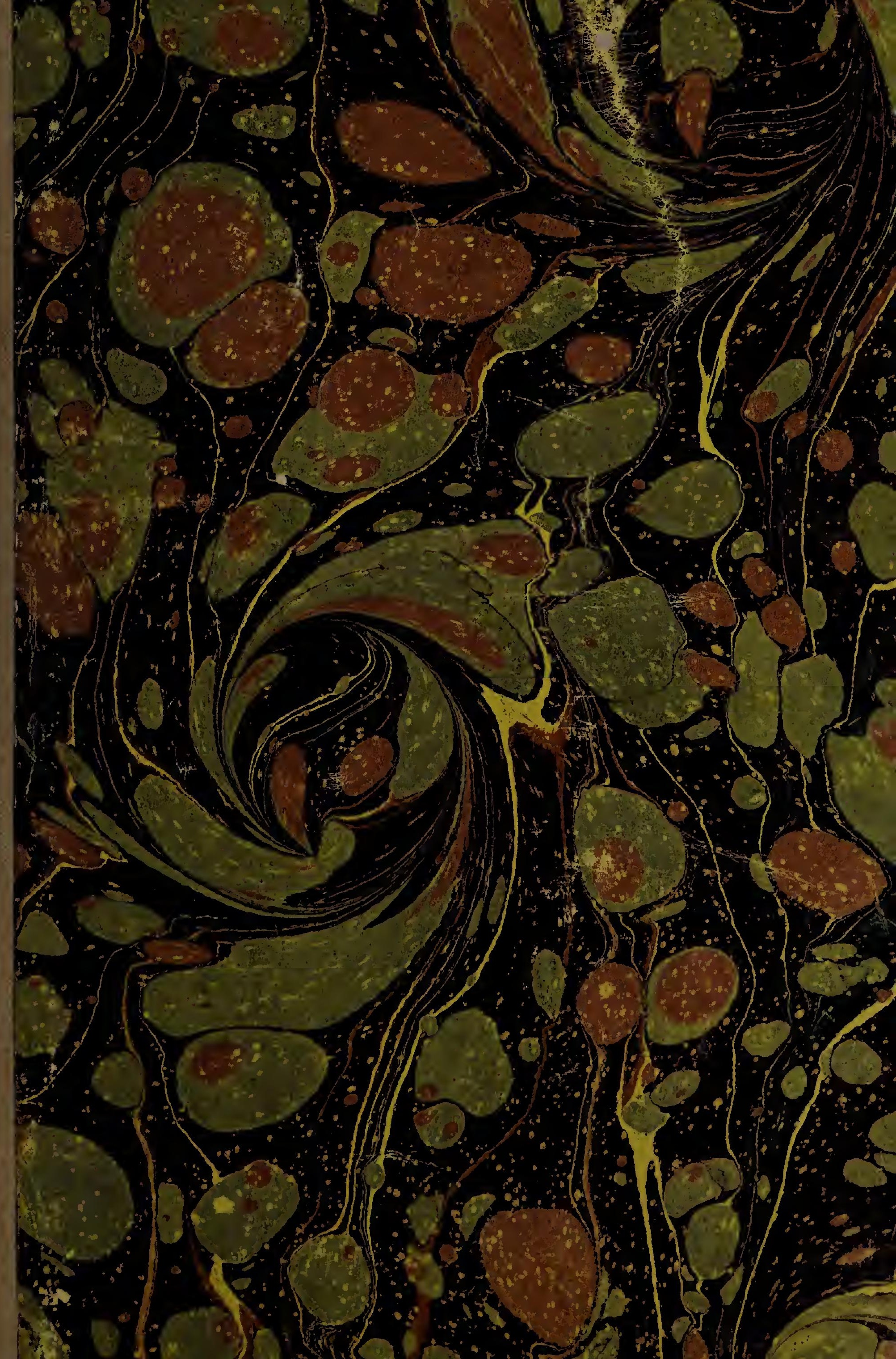


\section{HARVARD UNIVERSITY.}

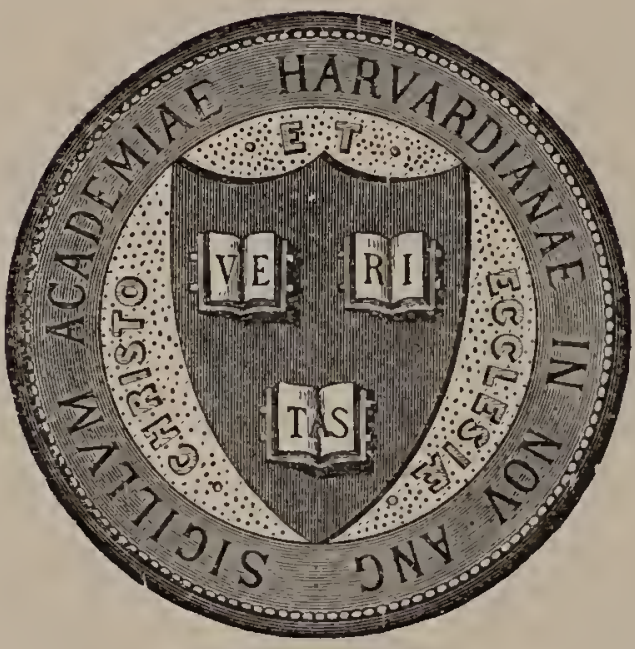

L I B R A R X

OF THE

MUSEUM OF COMPARATIVE ZOÖLOGY.

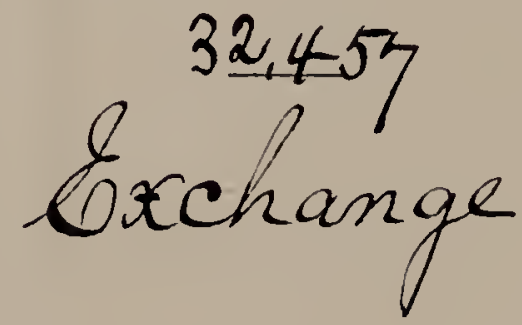

September 21.1908 


$$
32.457
$$

\title{
THE GAME RESOURCES OF ALASKA.
}

\author{
By \\ WILFRED H. OSGOOD, \\ Assistant Biologist, Biological Survey.
}

$r \sin$

[Reprint from Yearbook of Department of Agriculture for 1907.] 


\section{CONTENTS.}

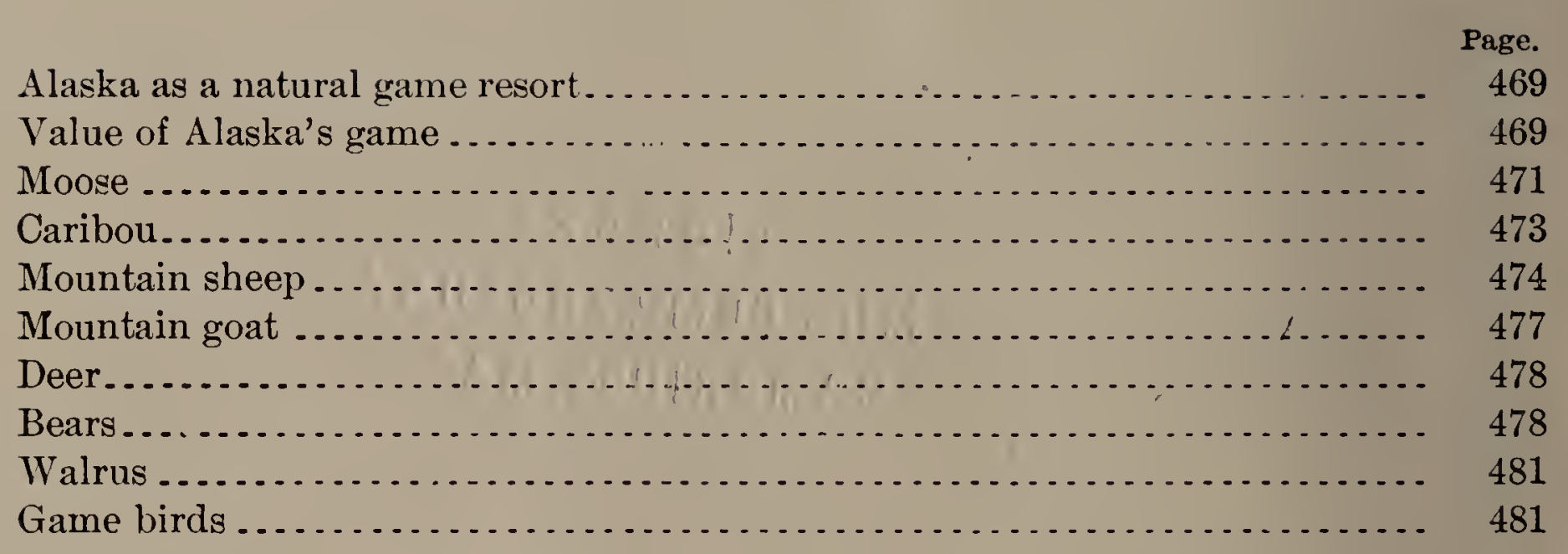

\section{ILLUSTRATIONS.}

I'LA'TES.

Plate LVI. The Alaska moose (Alce americanus gigas).................. Page. $474_{1}$ LVII. The white mountain sheep of Alaska (Ovis dalli) ............ 474

TEXT FIGURES.

FIG. 49. Distribution of moose and deer in Alaska . . . . . . . . . . . . . . . 472

50. Distribution of caribou and mountain goats in Alaska .......... 475

51. Distribution of mountain sheep in Alaska..................... 476 


\title{
THE GAME RESOURCES OF ALASKA.
}

\author{
By WILFRED H. OsGOOD,
}

Assistant Biologist, Biological Survey.

\begin{abstract}
ALASKA A NATURAL GAME RESORT.
\end{abstract}
The Territory of Alaska is of vast extent and possesses a varied climate, broad rivers, innumerable lakes, deep forests, and chains of lofty mountains -in short, many of the chief attributes of a natural game résort. Its barren northern shores, frequented by the lumbering walrus and the formidable polar bear, are washed by ice-laden currents, while its southern extensions support luxuriant forests inhabited by the graceful Sitka deer. Between these extremes are great interior forests, the home of the lordly moose, broad open tundras and rolling plateaus, traversed by herds of unsuspicious caribou, and snow-clad mountain ranges, the stronghold of sharp-eyed sheep and dull-witted goats.

Among Alaska's game animals are some of the largest and finest in the world, as the giant moose and the huge brown bears. The game of the entire Territory includes moose, caribou, deer, mountain sheep, mountain goat, walrus, and polar, brown, grizzly, black, and glacier bears, besides a variety of waterfowl, shore birds, and upland game birds. In game resources Alaska compares favorably with the western part of the United States in early days, and at the present time it is one of the most important game regions in the world.

\section{VALUE OF ALASKA'S GAME.}

Without entering into the general subject of the value of game to all countries possessing it, Alaska's game may be considered chiefly with reference to the features making it especially valuable.

Alaska is of particular importance as a game region because, of all American possessions, it is the one in which frontier conditions promise to last longest. Notwithstanding its wealth of mineral and other resources the Territory is not likely to be thickly populated, at least not for decades to come. It is true railroads already are beginning to penetrate its wilds and no doubt cities of considerable size will develop, but, even so, immense tracts far from populous centers will long remain in almost primeval condition. This is apparent from the great size of the Territory and its climatic and 
physiographic conditions. Its area is almost one-fifth that of the entire United States, and although much of this is economically full of promise it must not be forgotten that nearly one-fourth lies beyond the Arctic Circle and that a large proportion of the remainder consists of high mountains and inhospitable wilds. In the States irrigation is reclaiming many arid tracts and drainage is making it possible to utilize swamps and waste areas which now furnish refuges for game. From all parts of the country come reports of an increasing scarcity of game animals. Hence our remaining natural game preserves in Alaska are the more to be prized and correspondingly to be guarded. Within the United States certain kinds of game may be maintained for years on their original range, but for other kinds the reserve is inevitable, as no restriction of shooting can offset the constant diminution of the natural range they require. Thus most of the winter feeding grounds of the wapiti, or elk, already have been absorbed for agricultural purposes and the animals bid fair to be reduced to semidomestication, being fed like cattle in winter or confined to inclosed or restricted ranges. The same experience probably would have come to the bison, but its fate was decided more peremptorily. Very different, however, are conditions in Alaska, and, so far as can be seen at present, ample room for wild game will be available for years to come. The problem to be solved therefore relates only to saving the game itself.

Even if bison, elk, and antelope had remained abundant in the United States, still the game of Alaska would be of special interest because it includes many fine animals quite different from these in kind and in habits. The wholesome interest in nature study and outdoor life recently awakened in the United States is likely to bepermanent, and future generations, whether hunters, naturalists, animal photographers, or simply lovers of nature, will set a high value upon the possession of an undespoiled territory furnishing primitive haunts for wild game.

To the permanent inhabitants of Alaska the value of game is obvious. Indeed, although much game was killed during the early rushes of gold seekers, Alaskans generally have not been slow to appreciate the necessity of game protection and the sentiment in favor of it is growing rapidly. Prospectors and travelers in the wilderness must depend largely on game for food, and their necessities have been fully recognized in the game law. Considerable game also has been killed for consumption in small settlements where no regular supply of other fresh meat is available. However this be regarded, it is evident that restrictions must be placed upon the killing of game for sale in large towns where the demand is sufficient to endanger the very existence of the species. So far no species 
have been exterminated, but the traffic in wild game already is a matter of serious moment and difficult to regulate.

Besides serving as food, some of the animals are of local value for their skins, the whites having adopted many of the articles customarily used by Indians, as skin clothing, bedding, and footwear. Most Alaskans, although enjoying the sport, pursue game with utilitarian purpose, yet not a few hunt in regular season purely for the enjoyment of the outing, and by such the game is greatly valued, since it makes life more tolerable in a country where diversions are limited.

The game of Alaska has a very real money value. Each individual animal is part of a great interest-bearing capital. If all the game in Alaska were brought together in one large inclosure the animals so gathered would far outnumber those of the largest stock farm in the world. Assuming it possible to market such a herd a large sum of money would be realized. But a stock raiser does not market his entire herd unless retiring from business. He sells only the annual increase in order that the herd may maintain itself and assure an unfailing future income. Viewing the matter solely from a business standpoint a similar conservative course should be pursued with our stock of wild game, the extermination of which for the sake of immediate returns is absolutely indefensible.

In addition to its inherent value game is of great pecuniary importance to the country it inhabits on account of the money spent there by visiting sportsmen. Not only are substantial revenues derived through the direct sale of hunting licenses, but considerable sums are distributed in the payment of traveling expenses and in the employment of guides, packers, boatmen, and others. To Alaska and Alaskans such considerations are not without importance, for the development of this northern Territory will in the long run require the utilization of every resource. If lands unsuitable for mining or agriculture can, by reason of the wild game inhabiting them, be made a part of the permanent resources of the country, they have a substantial value. If properly husbanded the game becomes a perpetual source of pleasure and profit, whereas if it is ruthlessly sacrificed to immediate desires the region now made attractive by it will lapse into a comparatively uninteresting and useless waste.

Passing from general considerations, the several kinds of game resident in Alaska may be considered, with brief descriptions of the country they inhabit and a few words regarding their numbers, habits, and recent history.

\section{MOOSE.}

The Alaska moose (Alce americanus gigas) is the largest existing land mammal in America and the largest member of the deer family 
in the world. It is similar to the moose of eastern North America and the elk of the Old World, but exceeds them in size and differs somewhat in color and cranial characters. Its antlers reach magnificent proportions, almost rivaling those of the extinct Irish elk. The average spread from tip to tip is between 5 and 6 feet, while many pairs have been recorded having a spread of more than 6 feet. (See Pl. LVI.)

Moose are generally distributed throughout the timbered parts of Alaska, except in the southeastern coast region, where they are absent. On the Alaska Peninsula they range to the limit of timber and

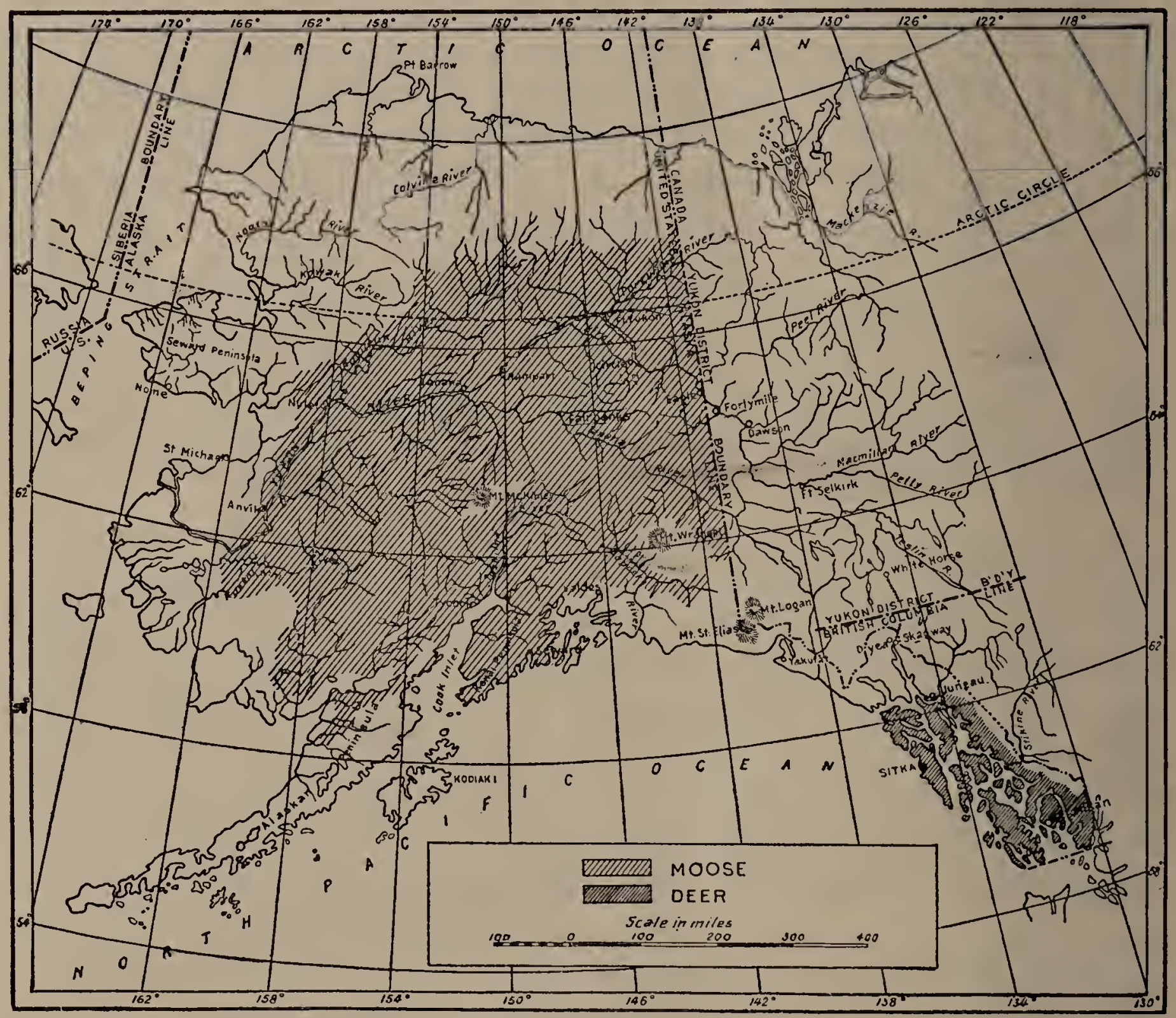

FIG. 49.-Distribution of moose and deer in Alaska.

in the north and west likewise reach the edge of the tundra. (See fig. 49.) In the mountains their tracks are so numerous on high rocky ridges above timber line that such places may well be regarded as a part of their regular range. But most of their time is spent in the mixed woods of spruce, poplar, and birch at moderate elevations or on the flats along the river bottoms where dense growths of spruce alternate with openings containing small ponds and grassy swamps bordered by thickets of willow and alder. The latter places are mostly sought during the season of flies and mosquitoes, to escape which the animals often lie for hours partly submerged in shallow ponds. In fall, 
although they may not entirely desert the low country, moose resort largely to the mountain sides and the scattered groves of trees near timber line. As to their winter habits little is known, but apparently they do not "yard," or at least not to such an extent as the eastern moose. The calves are born from early May to late June and follow the cows at least until the next spring. The rutting season begins about the middle of September.

Various methods of hunting moose are employed in Alaska. Of these still hunting is most common. Calling with the birch-bark horn, so successfully practiced in eastern Canada, is not greatly in vogue, but when properly executed is effective. Contrary to the custom in the East the imitation of the bull is used most frequently, although evidence that bulls can be attracted by the call of the cow is not lacking. In some instances dogs have been successfully employed. The Indian's lazy method of lying in wait near trails or ponds known to be frequented by moose is also practiced.

Although moose occur throughout practically all the interior of Alaska and in some places near the coast they are not uniformly distributed, and certain localities are much more favored by them than others. Beyond doubt they are more numerous on the Kenai Peninsula than in any other area of equal size, and here they attain a larger size than elsewhere. They are fairly common also in certain districts near the Yukon River between Eagle and Circle, while many less-known parts of the interior are much frequented by them.

\section{CARIBOU.}

Caribou inhabit the treeless and semi-treeless parts of Alaska, including the bare mountain ridges of the interior and the open rolling tundras of the coast from the Arctic Ocean to the Pacific side of the Alaska Peninsula. Throughout this region the greenish white lichen or "reindeer moss," which constitutes their principal food, is abundant. Except in crossing from one mountain ridge to another they rarely enter the timber and consequently are seldom seen by travelers on the main river highways. They scatter widely in summer and in fall collect in herds, often very large, but at all times they roam widely. The great herds in the fall of the year perform a more or less regular movement in the nature of a migration, and within certain limits their course of travel and times of arrival at given points are well known. Probably the best known of the large herds is the one which collects along the watershed between the Yukon and Tanana rivers. This herd still regularly musters from 1,000 to 3,000 or more animals, although levied upon annually by hunters from Forty Mile, Eagle, Circle, and the new mining towns on the Tanana River. Herds perhaps equally large range the little-known Arctic slope along the 
Endicott Mountains and adjoining parts of the northern Rocky Mountain system. and thence to the Arctic coast, and smaller ones throughout the length of the Alaska Peninsula. Thence inland to Mount McKinley and southward along the Nutzotin Mountains to the eastern side of the St. Elias Range scattering herds are distributed. (See fig. 50.) Except on the Alaska Peninsula caribou are very scarce on the coast of Bering Sea, where formerly abundant, having been driven out or extirpated. But elsewhere their original range is so little frequented by man that they retain most of it, though probably in greatly reduced numbers. Nevertheless, with the possible exception of the walrus and the large brown bears, the caribou are in greater danger of extirpation than any of the other large animals of Alaska. Like most gregarious animals, they are easily killed in large numbers and even when found singly or in small-herds display but little sagacity in eluding pursuers. Hence they fall ready victims to ruthless meat hunters and conscienceless Indians. Although chiefly living in open country they depend very little upon sight for protection, and their keenness of scent avails only slightly against hunters who know their habits. Once found it requires little skill to kill them, and although this tends to lower them in the eyes of genuine sportsmen they are still highly regarded, not only for the handsome trophies furnished by their antlers, but also on account of their interesting habits. They present especially inviting subjects for the animal photographer, but as yet no really good photographs of them have been taken.

Formerly the woodland caribou inhabited Maine and other northern States, but in recent years it has disappeared and may never revccupy its old territory. The caribou of Alaska, therefore, are the only ones now to be found in the territory of the United States. Though belonging nominally to three species, Rangifer arcticus, of northern Alaska, Rangifer granti, of the Alaska Peninsula, and Rangifer stonei of the Kenai Peninsula, they differ from each other only slightly. They are essentially barren-ground caribou, though the last (stonei) is somewhat larger than the others and shows some. resemblances to the large mountain caribou of British Columbia.

\section{MOUNTAIN SHEEP.}

Only one species of mountain sheep lives in Alaska, the white or Dall sheep (Ovis dalli). ${ }^{a}$ It differs decidedly from the well-known bighorn or Rocky Mountain sheep, being practically pure white in color, somewhat smaller in size, and having more slender and rather more gracefully curved horns. Its former range included practically

${ }^{a}$ Although sometimes attributed to Alaska, both the Rocky Mountain sheep (Ovis canadensis) and the gray or Stone's sheep (Ovis dalli stonei) find their northern limits in Canadian territory. 


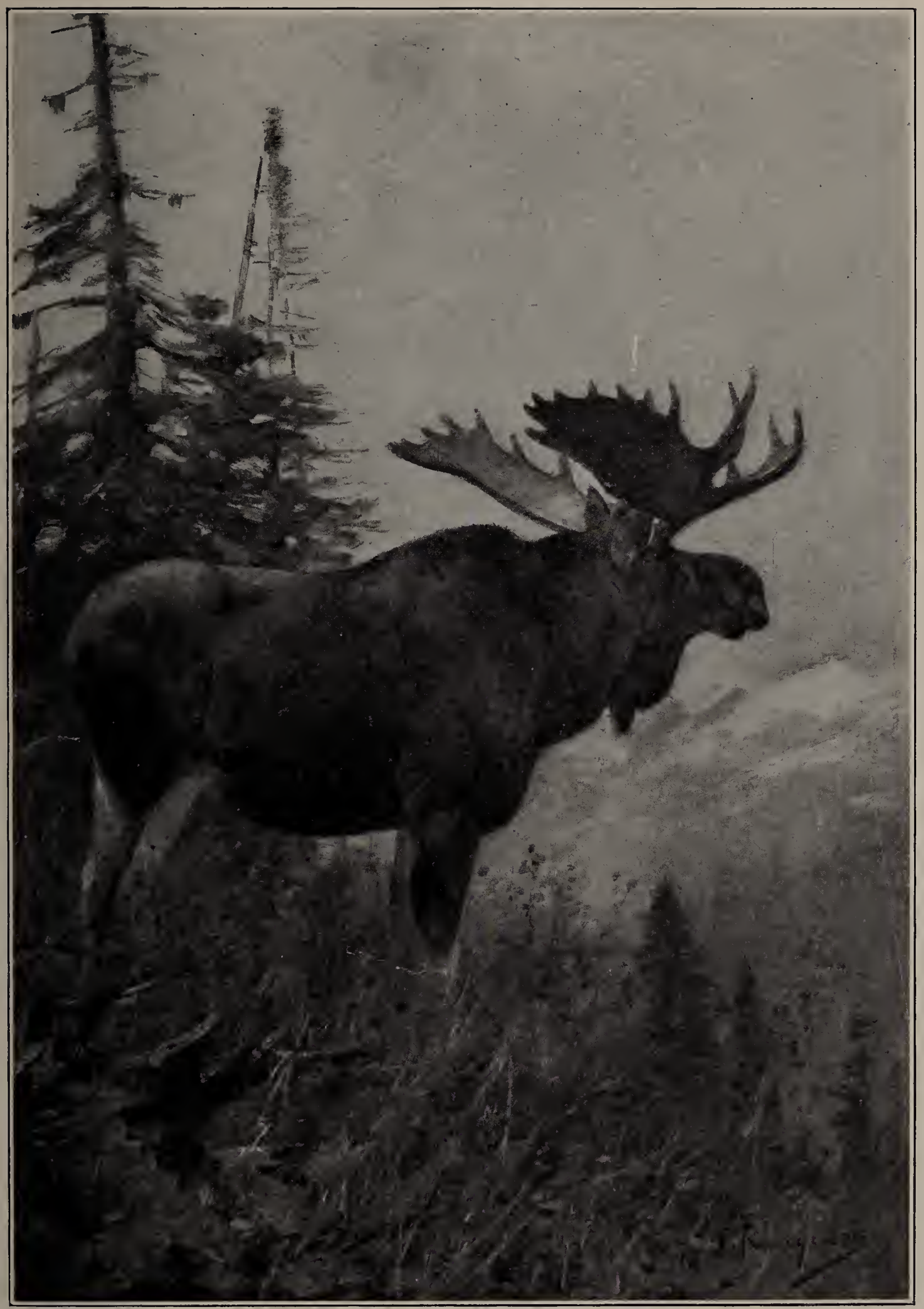

The alaska moose (alce americanus gigas). 



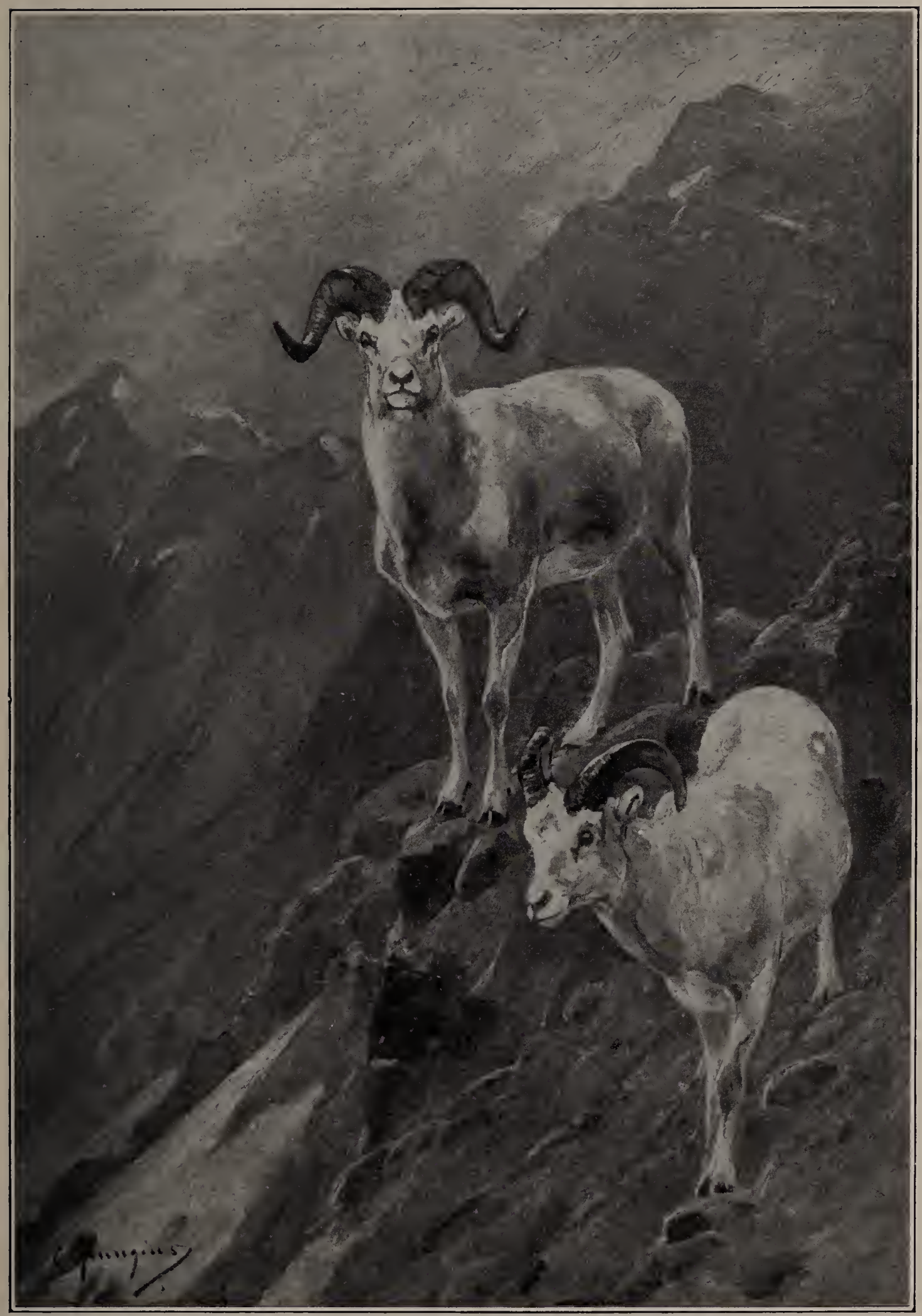

The White Mountain Sheep of alaska (OVIS dalli). 

all the mountains of the interior of Alaska and at present it is absent only from those mountains which lie near permanent settlements. It prefers the higher altitudes, and in any given group of mountains is usually most abundant about the main divide and the higher or more central peaks. It does not inhabit, and so far as known never has inhabited, the mountains of the Alaska Peninsula or the coastal slopes of the mountains of southeastern Alaska, but large numbers live on the Kenai Peninsula, the Endicott Mountains, Mount McKinley, and adjoining parts of the Alaska Range. It still lives in small numbers on some of the higher peaks between the Yukon and

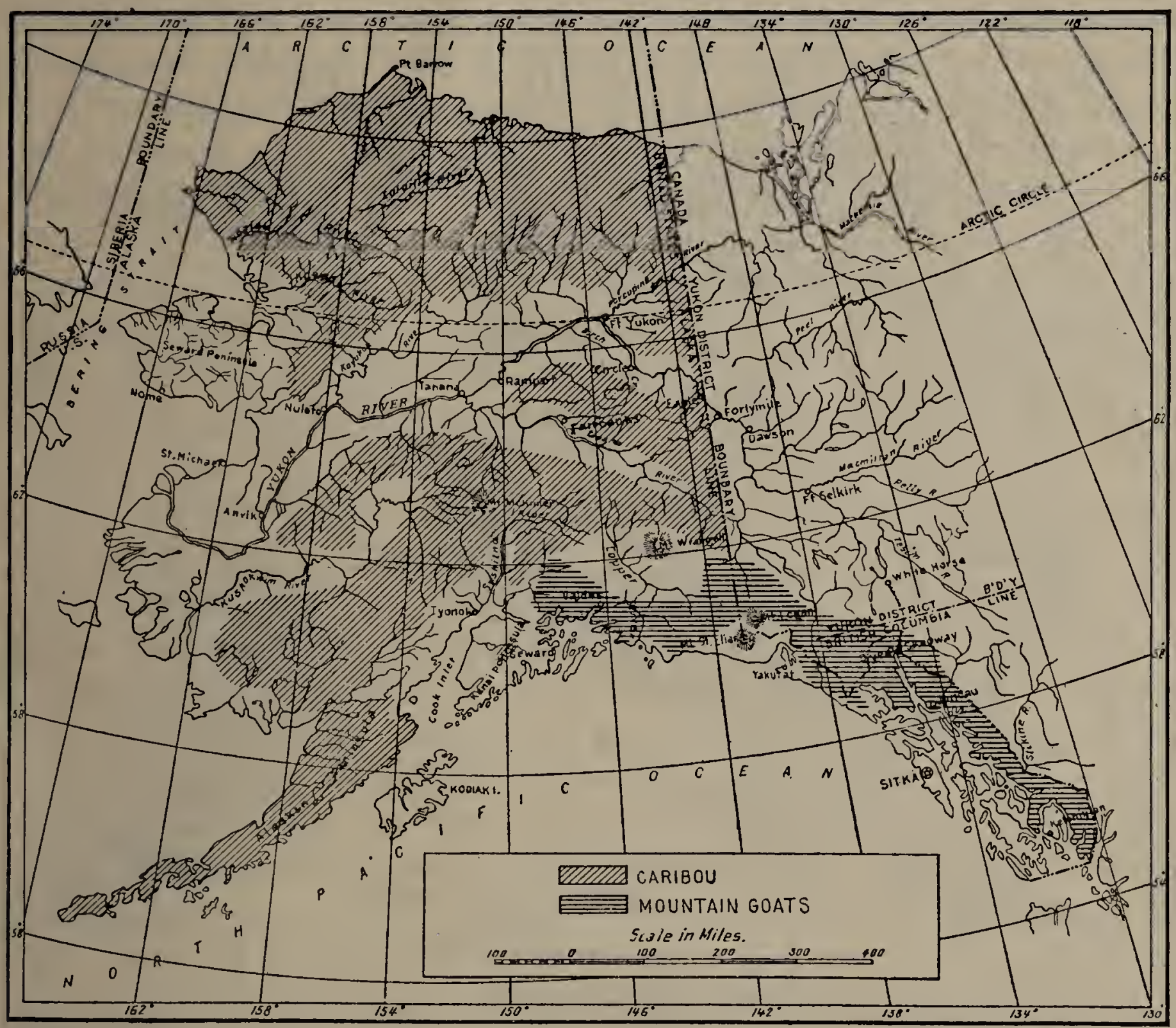

FIG. 50.-Distribution of caribou and mountain goats in Alaska.

Tanana rivers, but is in great danger of extirpation in this region It appears to range regularly on the Arctic slope north of the Endicott Mountains at rather slight altitudes, even to within a few miles of the coast. (See Pl. LVII and fig. 51.)

The habits of the white sheep are similar to those of kindred species. Their lives for the most part are spent on the wild, exposed, and forbidding mountain tops, but they do not hesitate to descend into timber. They may even take long journeys, passing all obstacles, swimming rivers, and traveling for miles through heavy forests, but their natural home, even during the severities of Arctic 
winter, is above timber line. In summer this is by no means an inhospitable region, for however numerous may be the cliffs, the rocky pinnacles, and the hanging snowbanks, below and around them are always the mountain gardens, saucer-like basins studded with tiny ponds, or long fan-shaped slopes traversed by trickling streams and luxuriant with low matted vegetation: The sheep feed largely on these high slopes and meadows, but move about a great deal, and their well-marked trails show that they visit almost all parts of the mountains. Although their reputation for agility and surefootedness is well founded, their trails seldom if ever pass through such

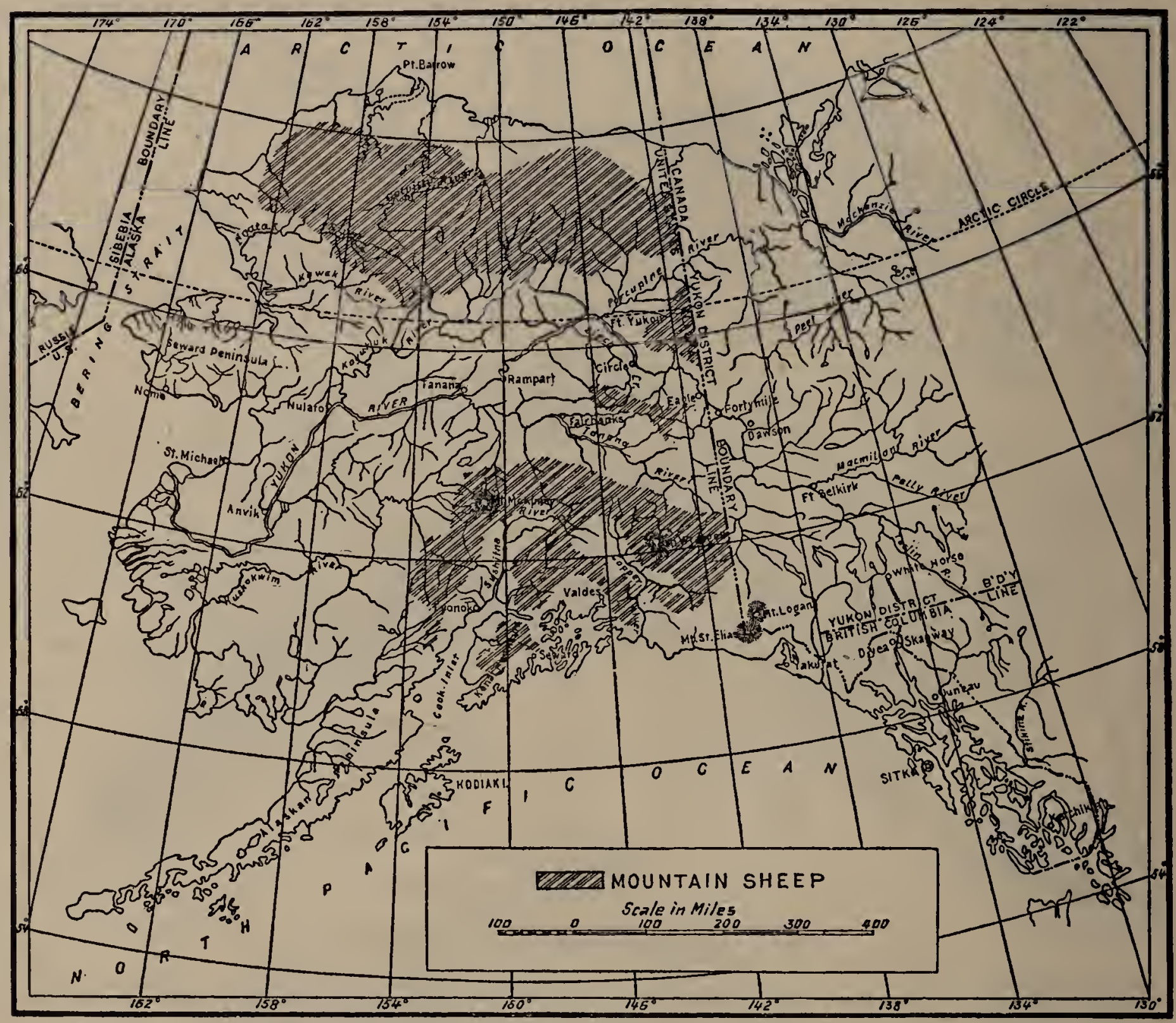

FIG. 51.-Distribution of mountain sheep in Alaska.

rough ground as to daunt an active man of experience. They are keen of vision and, unlike most game animals, depend little upon scent for warning of danger, but in spite of this it is no easy task to approach one of these alert, far-sighted animals on an open mountainside. To those physically equipped for it hunting mountain sheep is unquestionably one of the greatest of sports, and Alaska is one of the best fields for it in the world. To the inspiring and exhilarating joys of mountaineering are added the uncertainties and excitements of the chase. Whether bearing gun or camera the hunter 
pits not only his skill and cunning but also his strength and agility against those of the animal.

\section{MOUN'TAIN GOAT.}

The higher parts of the mountains of the southeastern coast of Alaska, although eschewed by sheep and caribou, are inhabited by white mountain goats (Oreamnos montanus). ${ }^{a}$ They are confined almost entirely to the coast side of the mainland mountains, as they rarely extend far into the interior or to the islands lying near the coast. Their range in Alaska is thus a narrow strip extending from Portland Canal northwest to the western spurs of the Chugach Mountains near the head of Cook Inlet. Although unevenly distributed goats are fairly common throughout most of this region and can be found within comparatively short distances of busy towns, as Ketchikan, Wrangell, Juneau, Skagway, and the settlements on Prince William Sound. (See fig. 50.)

With the exception of the pronghorn antelope the mountain goat is zoologically the most peculiar of American game animals, and with the possible exception of the musk ox its habits are the least known. Despite its name it is not a goat, nor is it an antelope, though having more in common with the antelopes than with the true goats. At present its nearest relatives are the curious Asiatic serows and gorals and the well-known chamois, all of which belong to a group collectively termed goat-antelopes. It lives almost entirely at high altitudes, frequenting steep cliffs, rock-walled canyons, and summits of an even more forbidding nature than those traversed by mountain sheep. To approach a mountain goat successfully is more a feat of mountaineering than of crafty hunting. This is partly because the goat keeps watch only over the country below him, so it is necessary to get above-and to get above a white goat is in most cases to get to the ultimate heights. But the scenery of the mountains on the Alaskan coast is among the finest in the world, and one who has good lungs and strong legs has little cause to regret that the goat leads him among crags and peaks.

The flesh of the mountain goat, except in young animals, is strong and not especially palatable, while its hide has little commercial value. Moreover, the animal can not be obtained by lazy methods, and hence is in no danger of extirpation. It has short, strong legs, a short neck, and a thick, heavy body, withal presenting a clumsy appearance quite the reverse of what might be expected from the precarious nature of its habitat. The horns, which are present in both sexes,

a The goats of the Alaska coast belong to the subspecies columbianus and liennedyi, distinguished by large size and cranial characters, but their respective ranges and relationships are not thoroughly known. 
are small, recurved, polished, and blackish. They range from 7 to 10 inches in length. The hair is long, shaggy, and, when unstained, pure white.

\section{DEER.}

Although the greater part of Alaska is without small deer (Odocoileus) the southeastern coast region or "panhandle" is greatly favored in this respect. Only one variety occurs, the so-called Sitka deer (Odccoileus columbianus sitkensis), but this one is exceedingly abundant, although the region inhabited by it lies well beyond the northern limits of any other American deer. It is a variety of the Columbia blacktail, from which it differs chiefly in smaller size, and in having the upper side of the tail more extensively brownish. Like the blacktail and mule deer, it is a "bounding" deer and in flight pursues a zigzag course, alighting on all four feet at once after each leap. Unlike the whitetail, it does not raise its tail or "flag" when running. In size it is small, ordinary. bucks weighing less rather than more than 100 pounds. Its rather small antlers are similar in form to those of the mule deer and are perhaps the least impressive of those of North American deer. It inhabits practically all the Alexander Archipelago and the adjacent mainland from British Columbia to the vicinity of Juneau. Throughout this region it ranges from seacoast to timber line in forests and undergrowth almost unequaled in density and luxuriance. Except for its great abundance this deer might be rarely seen, for its cunning is not less than that of others of its kind and its habitat affords unusual protection. But it occurs in such numbers throughout most of its range that in spite of the numbers killed in the past it still may be found with no great difficulty. Previous to the enactment of the Alaska game law deer were killed by hundreds and even thousands merely for their hides, which netted the hunter a few cents apiece. This ruthless waste is now stopped, and since good local sentiment bids fair to prevail the deer will doubtless hold their own. (See fig. 49.)

\section{BEARS.}

Alaska is without a rival in respect to number and variety of bears. No fewer than 13 kinds, as recognized by recent mammalogists, live in the Territory. These, however, belong to only 4 general types and fall naturally into 4 groups, the brown bears, the grizzlies, the black bears, and the polar bears.

The brown bears are the most numerous and most important. Zoologically their relationships are with the Old World brown bears rather than with any American species. They are of huge size, being much larger than the grizzlies and all other bears except the polar bear and their own relatives of Kamchatka. Therefore the state- 
ment, often made, that they are the largest carnivorous animals in the world needs little if any qualification. They are confined almost exclusively to the coast region, ranging from Bering Sea throughout the Alaska Peninsula and some outlying islands and thence south along the Pacific coast nearly or quite to British Columbia. Many of the islands of the Alexander Archipelago are inhabited by them and also the near-by mainland. Their color varies greatly, ranging from dark seal brown to buffy brown, the feet, legs, and underparts usually being darker than the shoulders and back. 'Although the ends of the hairs are often paler than the bases the silver-tipped effect of the grizzlies is wanting. "The front claws are shorter, thicker, and more abruptly curved than in the grizzlies.

It is often said that the brown bears are less ferocious than the grizzlies, but the evidence is conflicting. Certainly they are more powerful and at close quarters correspondingly dangerous. They come out of hibernation early in the spring, usually in April. When the salmon begin to run they feed largely on them and on this account have been called fish bears, or fish-eating bears, although other bears have the same habit. They eat a great variety of other 'food, however, including kelp and shellfish secured about the mouths of streams and along tide flats, and also berries, roots, ground squirrels, and mice obtained on higher ground.

The brown bears of Alaska will doubtless become very rare or extinct at no very distant date. Such formidable carnivorous animals, even though not inclined to attack human beings, are commonly regarded as a menace to the safety of travelers and therefore undeserving of protection. Already, they have become scarce on Kodiak Island where formerly very abundant, and on the Alaska Peninsula, though still fairly numerous, they are being killed at a rate probably greatly in excess of their increase. In the heavy forests of southeast Alaska and in the region of Mount St. Elias they may hold their own longer.

The varieties of brown bears as at present classified are as follows: The Kodiak bear (Ursus middendorffi), inhabiting Kodiak Island; the Alaska Peninsula bear (Ursus dalli gyas), of the Alaska Peninsula; the Yakutat bear (Ursus dalli), of the vicinity of Yakutat Bay and the coast north and south for undetermined distances; the Sitka bear (Ursus sitkensis) of Baranof Island; the Admiralty bear (Ursus eulophus), of Admiralty Island; and the Kidder bear (Ursus kidderi), of the Alaska Peninsula. With the exception of the last three; which are smaller than the others and of uncertain relationships, all the brown bears are similar in general characters and external appearance, the varietal distinctions being based mainly upon cranial characters obvious only to professional mammalogists. 
The grizzly bears of Alaska belong to at least two varieties, one (Ursus horribilis phaonyx) of the interior, the other (Ursus kenaiensis) of the Kenai Peninsula and adjacent coast region. They are generally distributed in these regions and although not common near settled and traveled parts are often met in unexpected places. Their habits are similar to those of the well-known grizzlies of the western part of the United States. They spend the summer chiefly above and near timber line and in such places are not infrequently encountered by the mountain sheep hunter. Like most bears, however, they are seldom caught unawares. They roam widely, are very keenscented, and get out of danger with great ease and alacrity. At present they are perhaps most numerous in the Endicott Mountains and the Nutzotin and Alaskan Mountains, including the region of Mount McKinley.

Black bears (Ursus americanus) are fairly common throughout all Alaska south and east of the treeless tundra. They are among the shyest of animals and many doubtless slip away without allowing themselves to be seen. Thus in many districts where fairly common they are supposed to be scarce. The cinnamon variety is very common in the interior but rare or almost unknown on the coast. The northern and interior black bears of Alaska are the same as those of eastern North America, but those of Prince of Wales Island off the extreme southeast coast appear to belong to a larger subspecies (Ursus americanus carlottce), in which the cinnamon phase is unknown.

Belonging with the black bear group is the rare and interesting glacier bear (Ursus emmonsi), inhabiting the southern slopes of the St. Elias Range and near-by mountains, at least from Cross Sound to the vicinity of Cape St. Elias. It is supposed to live near the numerous glaciers of this region, but its habits are practically unknown and, so far as reported, it has never been killed by a white man. Scarcely a dozen specimens, mostly imperfect, are contained in the museums of the world. The glacier bear is very similar in size and general characters to the black bear, differing mainly in color, which is silvery gray slightly mixed with black, the nose being brown and the feet blackish. In certain conditions of pelage the color has a somewhat slaty or bluish gray effect, hence the name "blue bear" sometimes applied to the animal.

The well-known polar bear (Thalarctos maritimus), which is no less common near the northern coast of Alaska than elsewhere in similar latitudes, completes the list of Alaska's bears. Owing to the remoteness of its habitat it is seldom seen except by whaling or exploring parties. During the cruise of the revenue steamer Comwin, E. W. Nelson found polar bears abundant about Herald Island and Wrangell Land in August, where doubtless they are still numerous. They have heen found occasionally in summer on islands in Bering 
Sea, notably St. Lawrence and Hall islands, but probably were left there by suddenly receding ice, so their occurrence in the summer season was accidental.

WALRUS.

Although the walrus is not always considered a game animal a paragraph may be devoted to it, since its imposing tusks are often sought by trophy hunters and since it has been protected by the Alaska game law. The Pacific walrus (Odobenus obesus), except for its larger size, is in all general features and in habits practically identical with the Atlantic animal. It is now rare south of Bering Strait, although formerly large numbers came south each season with the pack ice. In comparatively recent times also, several good-sized colonies of walrus lived throughout the year about the shores of Bering Sea, especially in Bristol Bay, but only the merest remnant of these is left. Unless earnest efforts are made to preserve this remnant not a walrus will be left south of the Arctic Ocean. On the Alaskan Arctic coast walrus still remain in considerable numbers, but even here their fate is uncertain, for no animal which produces articles of commerce is safe, however remote its habitat.

GAME BIRDS.

Alaska's game birds are mostly breeding waterfowl, the same wellknown migratory species which spend all or part of the winter in the United States. Therefore, while the Territory is highly important as a refuge for large game, it is scarcely less so as a shelter for our surviving water birds. Ducks, geese, and wading birds, so recently abundant on our coasts and inland waters, are every where diminishing in numbers, and more than one species is threatened with extinction in the near future. Under such circumstances the innumerable ponds of the interior of Alaska and the lonely tundras of its northern coasts, in which many of these birds rear their young, become of the utmost importance. The birds arrive in the north early in the spring in April or May and after breeding leave for the south in August and September. Among them are great numbers of ducks, geese, swans, and vast hordes of small shorebirds, as plovers, snipes, curlews, and sandpipers. A large proportion of these stop in the United States in the fall or spend the winter there. Protective laws in the States therefore avail but little unless the birds are fully protected also on their breeding grounds. In proportion to the population pot hunters are no less numerous in Alaska than elsewhere. In fact they are perhaps more numerous, on account of the relatively large number of people leading an outdoor life and accustomed to the use of firearms. A further bad feature is the fact that most of the shooting is done on the arrival of the birds in the spring on their way to the breeding grounds. 
Spring shooting is bad enough in the States, but in Alaska it is much worse, for every migrating bird has already escaped a multitude of previous dangers and, as it is just about to breed, is equivalent to at least four or five in the fall.

The gallinaceous game birds of Alaska consist of several varieties of ptarmigan and five species of grouse. The ptarmigan inhabit all the higher mountain tops of the coast and interior and the tundras of the Bering Sea and Arctic coast, including all the Aleutian Islands. Three principal varieties are permanent inhabitants of the Territory, the willow ptarmigan (Lagopus lagopus), the rock ptarmigan (L. rupestris), and the white-tailed ptarmigan (L. leucurus). They gather in immense flocks in the fall, frequenting low willow scrub, open tundras, and treeless mountain tops. Their flesh is relished in the north country, but is excelled by that of many other birds. The most common grouse is the Alaska spruce grouse ( $C a n a-$ chites canadensis osgoodi), generally distributed in the interior and reaching the coast in the vicinity of Cook Inlet. It does not fly well and is usually killed with a small rifle while perched in a tree. Its flesh is fairly good at certain seasons and often finds its way to the prospector's frying pan. The gray ruffed grouse (Bonasa umbellus umbelloides) also inhabits most of the wooded interior and is no less a delight to the sportsman and epicure than its well-known eastern relatives. The sooty grouse (Dendragapus obscurus fuliginosus) is fairly common along the Pacific coast from British Columbia to Cook Inlet. It inhabits heavy forest and, like the spruce grouse, is usually hunted with a small rifle. Two other grouse are rare and seldom seen, the Columbian sharp-tailed grouse (Pediocetes phasianellus. columbianus), of limited distribution in the interior, and the Franklin grouse (Canachites franklini), recorded once from southeastern Alaska. 


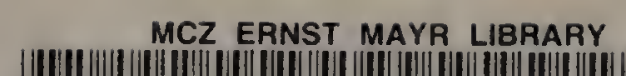 \\ $32044 \quad 128440211$}


